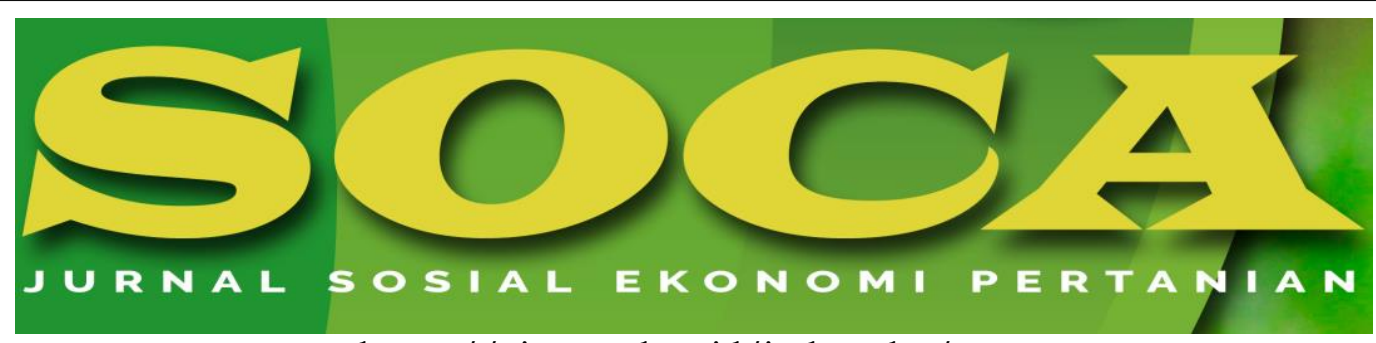

https://ojs.unud.ac.id/index.php/soca

\title{
The Effect of Motivation and Discipline Culture Optimalization on Worker's Work Performance in Buana Tunas Sejahtera Company (Inc.) Kapuas Hulu Regency
}

\author{
Irfan Risyadi, Dewi Kurniati and Anita Suharyani \\ Agribusiness Department, Agricultural Faculty, Tanjungpura University, Pontianak, West \\ Borneo \\ Email: irfanrisyadi19@gmail.com \\ Mobile: 082149812886
}

Submitted: 20 December 2019; Revised: 27 January 2020; Accepted: 19 February 2020

\section{Keywords: \\ AHP; \\ Worker; Discipline; Motivation}

\begin{abstract}
Abstrak
Nowadays, many companies in Indonesia are running in the plantation field. Buana Tunas Sejahtera Company (Inc.) is a palm oil company in West Borneo Province that working under the Kencana Group. This company was organized by leaders, directors, managers, manager assistants, foremen, clerks, permanent workers, and freelance workers. The worker's work performance in this company was slightly low due to their worker's low motivation and discipline. This study aimed to know the method to improve the workers' work performance in Buana Tunas Sejahtera Company (Inc.), Kapuas Hulu Regency. This was a descriptive quantitative study employing an Analytical Hierarchy Process (AHP) done by software namely Expert Choice 11. There were 100 workers chosen by the purposive sampling technique participated in this study. The result showed that the key point in dealing with the worker's work performance issue was meeting their social need, while improving their salary was a key point in dealing with the motivation issue. Building the worker's responsibility was playing an important role in improving the discipline culture. The company needs to improve the worker's motivation by conducting training sessions, increasing worker's salaries during the overtime hours, and giving more motivation to their workers. To improve the discipline culture, the company needs to use clear and firm rules to enforce the proper and accountable behavior among the worker.
\end{abstract}

How to Cite (APA 6 ${ }^{\text {th }}$ Style):

Risyadi, I., Kurniati, D., \& Suharyani, A. (2020). The Effect of Motivation and Discipline Culture Optimalization on Worker's Work Performance in Buana Tunas Sejahtera Company (Inc .) Kapuas Hulu Regency. SOCA: Jurnal Sosial 
Ekonomi Pertanian, 14(2), 302-312. https://doi.org/SOCA: Jurnal Sosial Ekonomi Pertanian https://doi.org/10.24843/SOCA.2020.v14.i02.p10

\section{INTRODUCTION}

Improving the national economy sector through an agribusiness is an effort implemented by the Indonesian government in improving the national economic stability. The plantation company is categorized as agribusiness activity that able to produce high profit. There were various type of plantation company in Indonesia. A palm oil plantation company was the dominant type of company founded in Indonesia. In 2018, there were 1,756 palm oil plantation companies spread in Indonesia (National Institute of Statistical Data, 2018).

A developing palm oil plantation company was characterized by its integrated palm oil company that able to reconstruct the infrastructure and utilizing human resources around the company. Recently, the number of this type of company is growing, which also indicated that their worker's social and economic wellness is improving. On the other side, the increasing number of this type of company could increase the level of product competitiveness among each company. To win the competition, a high work performance is required to maintain the product quality produced by the company.

A supporting factor must be well utilized by the company to reach its goal. Human resources is a crucial supporting factor in running a company. A company has to manage and involve a skillful and experienced human resources in a company. A highly potential human resource must be placed as the leader, supervisor, or a specific staff position that able to help the company reaching its goal.

Motivation is a key in improving working performance. Motivation drives workers to perform their best skills in working. Worker with high motivation usually have a high motivation during working. Discipline culture is also majorly affected the working performance. A good discipline culture could be shown by the presence of good working performance without any pressure from the company supervision. A worker with good discipline wouldn't be violating the company rule, but always try to obey the company rules instead.

Buana Tunas Sejahtera Company (Inc.) is a palm oil company under the Kencana Group that located in Seriang Village, Nanga Badau District, Kapuas Hulu Regency, West Borneo Province. This company was organized by leaders, directors, managers, manager assistants, foreman, clerks, permanent workers, and freelance workers. This study was only focusing on the permanent workers due to the low working performance, low motivation, and low discipline culture among them.

The permanent worker in this company was working in several types of fields, they were harvesting, preserving, nursery, fertilization, and castration field of working. The permanent workers tend to have low motivation and discipline during working. It was shown by their low work performance in the fertilizing area, disobey the company working hours (arriving late and leaving too early), rarely showing their best skill during working, and keep postponing their work. This could be happened due to lack of supervision, lack of motivation, and lack of salary given by the company. An effort need to be designed to improve the worker's motivation and 
discipline culture that able to prevent a significant decrease in the commodity quality and massive loss on the company party.

Based on Abraham Maslow's theory, there are some indicators used to measure the working motivation: (1) physiological need; (2) safety need; (3) social need; (4) self-esteem; and (5) self-actualization need. While the indicator for the discipline culture was (Hasibuan, 2005): (1) attitude (the worker attendance, the ability in using equipment), (2) norm (their willingness and ability to obey the company rules, their ability in following the company's standard operational procedure), and (3) responsibility.

A study done by (Hariyanto \& Satoto, 2016) found that the main priority or key factor chosen to improve the work performance was human resources. This study was contrary to a study done by (Purnomo \& Suprapto, 2015) that found social need and responsibility was the main priority in improving the worker's work performance. Social need was contributing an important role in improving worker's motivation. Responsibility was defined as the worker's ability in completing the task in a certain time given by the company and able to be accountable to all decisions made (Yusuf, 2018). The responsibility in improving the discipline culture consisted of diligent trait, high dedication, accountability, and good coordination.

This study aimed to know the key factor in improving worker's performance in Buana Tunas Sejahtera Company (Inc.), Seriang Village, Badua District, Kapuas Hulu Regency. This study expects to provide information about the key factor in improving the worker's performance which can contribute to the decision taken by the company in designing an effective method to improve their workers' work performance, motivation, and the discipline culture.

\section{RESEARCH METHODS}

This study conducted in Buana Tunas Sejahtera Company (Inc.), Seriang Village, Badua District, Kapuas Hulu Regency. The study location was chosen using a purposive sampling technique. Buana Tunas Sejahtera Company (Inv.) was having the largest palm oil plantation in Kapuas Hulu Regency.

This was a quantitative descriptive study employing 100 permanent workers chosen from 1.168 workers who working as the harvesting worker, preserving worker, fertilizing worker, and castration worker in Buana Tunas Sejahtera Company (Inc.). The data was collected by a questionnaire provided by the researcher. The motivation variable was measured by the physiological need, safety need, and social need, while the discipline culture was measured by the worker attendance, the ability in using equipment, their willingness and ability to obey the company rules, their ability in following the company's standard operational procedure, and responsibility.

\section{RESULT AND DISCUSSION}

\section{Participant's Characteristic}

The participant's characteristic was classified based on the age, gender, the working experience, type of work, and education. 100 labors in Buana Tunas Sejahtera Company (Inc.), Kapuas Hulu Regency participated in this study. 
Table 1. Participant's Characteristic

\begin{tabular}{lccc}
\hline $\begin{array}{l}\text { Participant's } \\
\text { Informatiom }\end{array}$ & Category & Frequency & Percentage (\%) \\
\hline Gender & Male & 67 & 67 \\
& Female & 33 & 33 \\
\hline Age (years) & $24-29$ & 6 & 6 \\
& $30-35$ & 21 & 21 \\
& $36-41$ & 50 & 50 \\
& $42-49$ & 23 & 23 \\
\hline Working Experience & $2-3$ & 7 & 7 \\
& $4-5$ & 28 & 28 \\
& $6-7$ & 50 & 50 \\
& $8-10$ & 15 & 15 \\
\hline Type of Work & Permanent & 34 & 34 \\
& Cultivation & 15 & 15 \\
& Seed Nursery & 13 & 13 \\
& Fertilization & 16 & 16 \\
& Castration & 22 & 22 \\
\hline Education & Elementary School & 45 & 45 \\
& Junior High School & 37 & 37 \\
& Senior High School & 18 & 18 \\
\hline
\end{tabular}

Source : Research Result Data (processed, 2019)

The most participant was aged between 36-41 years old. The working motivation tended to be higher in older age. The middle-age workers were having a lower level of motivation than the older worker, but the motivation usually increase as they getting older. This happened due 36-41 years old is categorized as productive age (Zein, Setyaningrum, \& Marlinae, 2016).

The most participant was male. This company was recruited more male than female workers due to the type of work that must be done in the company. (Febrinawati, Eliza, \& sayamar, 2015) also stated that the plantation of field type of work is required more male than female workers.

The dominant worker's working duration found was 6-7 years, while the company has been operating for 10 years. The working duration was determined the worker's ability and experience they obtained during working in this company. The level of working satisfaction also determined by the working duration (Febrinawati, Eliza, \& sayamar, 2015). The longer working duration would contribute to a better working experience. A worker was stated to have a qualified working experience if already understand and able to do their part in a job comprehensively (Yuningsih \& Pasaribu, 2014). 
The type of worker who majorly participated in this study was the harvesting worker due to a clear productive indicator of this type of worker. The indicator could be seen by the difference between the harvesting result and the type of jobs that set by the company. The permanent workers were important to increase the commodity produce by a company (Brindianes, Kemala, \& Busyra, 2017). Therefore, a company usually recruited more permanent workers to achieved the goals set by the company.

The participant's dominant education level was elementary school. This indicated that their education level was still low which contributed to a low level of knowledge and skill. A worker with a low level of education is mostly working on a field that needs more physical power than intellectual power. They also would find difficulties in working on the government of private organizations due to the low level of knowledge and skill. They usually obtain a low position that contributed to a low level of salary (Yulihartika, 2018).

\section{Weight Pairwise Comparison on Criteria and Alternative}

\section{Weight Pairwise Comparison on Motivation Criteria}

The evaluation on this level done by analyzing weight value on each variable. According to the hierarchy arranged in this study, we analysis factor affected the motivation and discipline to improve worker's work performance in Buana Tunas Sejahtera Company (Inc.), Kapuas Hulu Regency.

\footnotetext{
Priorities with respect to:

Goal: Peningkatan Kinerja (Motivasi)

Kebutuhan Fisiologis

Kebutuhan Rasa Aman

Kebutuhan Sosial

Inconsistency $=0,00023$

with 0 missing judgments.
}

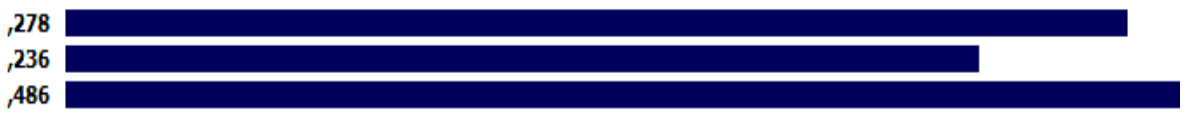

Figure 1. Normalization Matrix of Pairwise Comparison between Motivation Variable Graphic

Source: Data Analysis, 2019

Based on Figure 1, the social need was having the highest weight (conducive state) and conflict on a large scale rarely happened. The workers came from various social backgrounds (races, religions), but they able to maintain a good solidarity and tolerance toward each other. The company also providing worship places for the workers to build a good social relationship with their workers. This situation can indicate that the social need for this company was quite satisfying.

Most of the participants were agreed that social life was important for them. The most permanent workers were coming from outside of Borneo (mostly came from Java Island). Sixty-five percent of the permanent workers came from outside Kapuas Hulu area. Therefore, maintaining good social relations was very important during working in this company. It help them in understanding and helping each other in all life situation. The cultural differences in their working place was demanded an ability to adapt quickly. A good social situation would help them in adjusting to their new life. 
Social need was the priority that affected the working motivation. While the physiological need was placed in the second priority and the safety need was placed in third priority. According to the result, the participant was stated that good social relations would help them to create good collaboration with other workers, solidarity, strong emotional bonding, and able to avoid unnecessary conflict. Good social situations would help them to fulfill their physiological and safety need, such as sharing food with other workers and taking care of other workers safety.

The social need is important in building a good social relationship. Humans are social beings, they couldn't live properly without others. Human are also open and free to own something. Humans can do their responsibility sustainably on each decision they took. The nature of humans is living in a group rather than living alone (Sutrisno, 2012). Human needs to actively interact with each other to live as a social being. Social interaction is the main requirement in building social activities. Social interaction is ranged on some type of relation: between individuals, between groups, and between individuals and groups.

The result indicated that the worker's social need in this company is well fulfilled that would significantly affect the worker's motivation. This result was parallel with a study done by (Purnomo \& Suprapto, 2015).

\title{
Weight Pairwise Comparison on Discipline Criteria
}

\author{
Priorities with respect to: \\ Goal: Peningkatan Kinerja (Kedisiplinan)
}

Kehadiran Karyawan
Menggunakan Perlengkapan Dengan Baik
Mematuhi Aturan
Mengikuti Cara Kerja Perusahaan
Tanggung Jawab
Inconsistency $=0,03$
with 0 missing judgments.

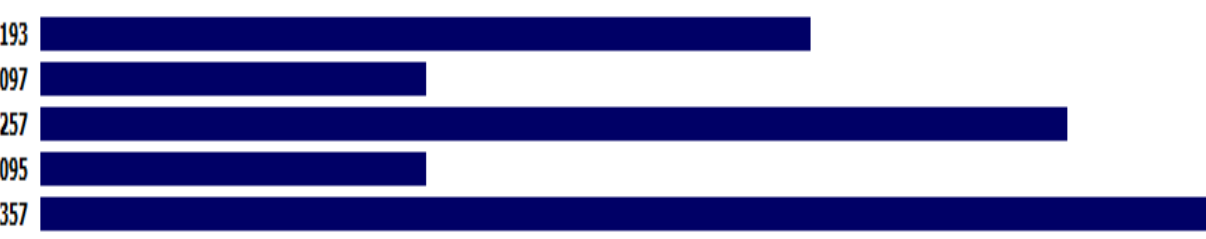

Figure 2. Normalization Matrix of Pairwise Comparison between Discipline Variable Graphic

Source: Data Analysis, 2019

According to the Figure 2, the responsible variable was having the highest weight. The worker's responsibility was quite good which is shown by appropriate clothes worn by the worker during working, the active participation in the morning briefing, and obey the foreman's instruction. But some workers did not show good responsibility during working which was shown by did not concentrate enough during working and using the working hours to rest. The harvesting permanent workers must be able to reach the company target in harvesting the palm oil (one ton of palm oil commodity in a day), where a lack of responsibility would affect the company production significantly. Therefore, responsibility was very important in managing work and reaching the target set by the company.

The responsibility was the main priority, while obeying the rule was being the second priority and the worker's presence was the third priority. Responsibility was 
placed in the main priority because the participants agreed that responsibility would affect the obeying rule and the worker's presence variable. The responsibility drives the worker to be always present their best skill and discipline during working, including to obey the rules and always working based on the schedule organized by the company.

Worker with good responsibility supposed to manage the work given by the company properly while using their best skill to finish the work in a certain time set by the company. They also must be accountable for each decision they took during working. The good responsibility also reflected by their high dedication, diligent trait, and accountability on each task they do.

This result was similar to a study done by (Simanjuntak, Uker, \& Zuki, 2019) which found that responsibility was a variable that majorly affect the discipline culture among the workers. The responsibility would prevent working task finished by violating the rule or impacting a loss on the company party.

\section{Weight Pairwise Comparison on Motivation Alternative}

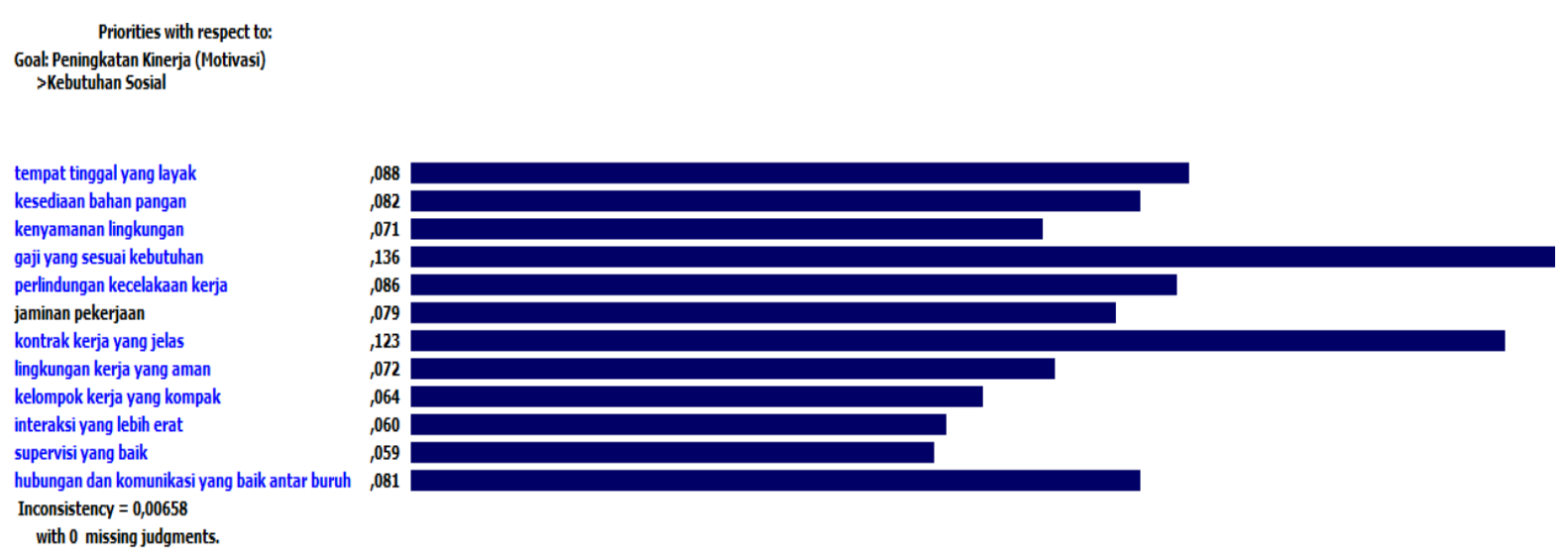

Figure 3. Normalization Matrix of Pairwise Comparison between Motivation Alternative Graphic

Source: Data Analysis, 2019

According to Figure 3, the amount of salary obtained the highest weight. The basic salary given by Buana Tunas Sejahtera Company (Inc.) was as much as IDR 23 million in the month. The amount of the salary was considered as an appropriate amount of salary according to the Kapuas Hulu Regional Minimum Wage (IDR $2,483,000$ ) (Department of Labor and Transmigration, 2020). But most of the workers stated that the amount of the salary was relatively low due to the high staple food cost and the technical problems happened during working which able to reduce their salary. Therefore the most of the workers were taking the overtime hours to get a higher salary. The overtime hours could be taken during the weekend days.

The amount of salary was considered as the most important alternative. An interview done with a worker name Kartono found that:

"If the salary can cover all our daily life needs, my wife doesn't need to open a small shop in my home. I need a quite big amount of money for paying the motorcycle credit and my children school tuition. The salary given by the company was not enough for us. My wife couldn't work as a worker in the same company as me because she 
should be taking care of my children, that's why we open a small shop in our home as another effort in gathering more money for our life."

The result of this interview was indicated that the salary was not able to cover all the worker's needs.

The amount of salary accepted by the worker wasn't enough to cover all the worker's daily life needs. An effort to increase their salary by working in overtime hours and reaching the goals targeted by the company also couldn't fully help the worker to raise the amount of salary. Some technical issues during the plantation process (fertilization issues, the low number of palm oil harvested) was become the main hindrances in rising the amount of salary. Most of the participants stated that the main purpose to be working in this company was getting the salary. But unfortunately the salary doesn't able in covering up their daily life need.

The amount of salary accepted by the worker was varied. It depended on their presence, overtime hours, and bonus accepted. The worker with a good number of presence would accept a high amount of salary. Some workers also took overtime hours voluntarily to increase the amount of salary they accepted. The amount of salary on the worker who working in the overtime hours would be higher than the amount of salary of the worker who did not work overtime hours. Workers who able to work well and reached the goal targeted by the company would also get a higher salary.

The main priority was the amount of salary, the second priority was a clear working contract, and third place was a decent place to live during contracted as the worker. The amount of salary was placed in the priority because it was becoming their first purpose in working in the company. The clear working contract and decent place to live were not considered as the priority because it couldn't cover their primary and secondary living cost.

The amount of salary was the main priority that affected the working motivation. The amount of salary motivated the worker to work and reach the goals targeted by the company. We suggested the worker and company made an agreement that contains a set of amount of salary and a set of rules that must be followed by the company and worker. This was parallel with a study done by (Febrinawati, Eliza, \& sayamar, 2015) that found the salary was being the main priority in improving worker's motivation. If the amount of salary accepted was created the level of selfsatisfaction among the workers.

\section{Weight Pairwise Comparison on Discipline Alternative}

According to Figure 4, the responsibility was placed as the alternative with the highest weight. During the study, most of the worker was trying to be responsible in doing their work, such as harvesting the palm oil based on the company's standard operational procedure, doing fertilization completely, and keeping their good work performance.

Responsibility was placed in the first place because if the worker was able to put their responsibility in the work they do the company's goal would be able to achieve. For example, if the harvesting worker reaches the goal targeted by the company, they would obtain a score of 100. This was indicated that their harvesting quality was categorized in A level (reach the targeted volume production, good quality 
of palm oil harvested). The Buana Tunas Sejahtera Company (Inc.) was given a bonus to a worker who able to present their best skill during working and capable in reaching the company goal. This bonus system successfully motivate the permanent worker to work better. A higher production volume and palm oil class achieved, the higher level of bonus would be obtained.
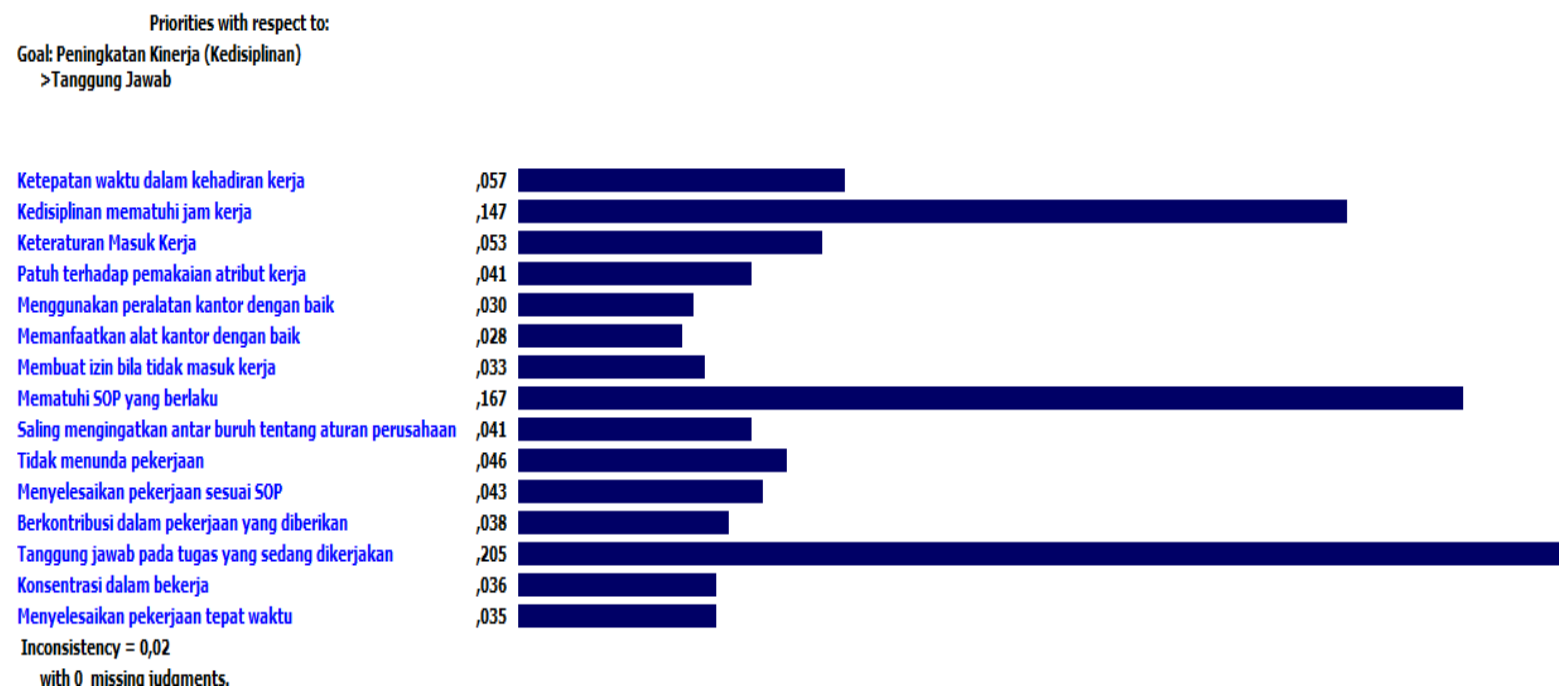

Figure 4. Normalization Matrix of Pairwise Comparison between Discipline Alternative Graphic

Source: Analysis Data, 2019

Responsibility was majorly contributed to the work done by the worker. The harvesting worker was responsible for the number of palm oil harvested/per day, if a harvesting worker couldn't put good responsibility in their work, the harvesting worker couldn't reach the target of palm oil harvested in each day. An interview done during the study showed that some workers were not able to show their responsibility during working. They were caught negotiating the working schedule with foreman. The workers were offering cigarettes as the compensation for the foreman if the foreman didn't put them to work in a hilly area. This negotiation was a form of violating the company's rules and loss on the other worker's party. The company already declared that the worker's place of work must be divided fairly. All the workers must be alternately working on the hilly area. Therefore, each worker must be responsible for their work, so there were no parties on the loss side.

The responsibility was placed as the main priority, obeying the standard operational procedure was the second priority, and obeying the working hours was placed the third priority. The responsibility was put on the first place because it could affect the worker's behavior in obeying the standard operational procedure and working

Therefore, workers were demanded to work based on the discipline culture and obey all rules set by the company. The worker also expected to implement the rule based on theirs "self-awareness". This is done to make the workers voluntarily obeying the rule, without any compulsion applied by the company. 
Responsibility was placed on the priority because it reflects the worker's accountability in managing work given by the company. If the worker can manage the time wisely, the worker would be able to manage the work optimally.

Yusuf (2018) stated that responsibility is an ability in managing the work optimally and complete it in a certain time given coupled with the capacity to be accountable for the risk that appeared as the consequences on the decision taken. Responsibility in improving the discipline consisted of diligent traits, high dedication, good coordination, and efficient and effective work.

\section{CONCLUSION}

We concluded that the main priority or key point in improving the worker's work performance on the motivation variable was the social need and on the motivation alternative was salary. While the main priority or key point in improving the worker's work performance on the discipline variable and alternative was the responsibility variable.

\section{RECOMMENDATION}

Buana Tunas Sejahtera Company (Inc.) requires to use the alternative priority or key point in improving motivation and discipline culture among the workers. We suggested the company to closely attentive to the worker's physiological needs, for example in managing the staple food's price for the worker. This is important due to the worker's willingness in saving money for their daily life need. The company also must supervise the worker's responsibility in managing the task given to them, a reward and punishment also could be the given to motivate the worker to present their better skill and performance during working.

\section{REFERENCES}

Brindianes, S., Kemala, N., \& Busyra, R. G. (2017). Produktivitas Tenaga Kerja Panen Kelapa Sawit Dan Faktor-Faktor Yang Mempengaruhinya Pada Unit Usaha Batang Hari Di PTPN IV Jambi. AGRICA , 10 (1), 74-85.

Disnakertrans Kalbar, 2020. UMP dan UMK Kabupaten / Kota Provinsi Kalimantan Barat Tahun 2020. Pontianak: Disnakertrans Prov Kalbar

Febrinawati, Eliza, \& Sayamar, E. (2015). Analisis Kepuasan Karyawan Bekerja Di Ptpn V Kebun Sei Kencana Desa Senama Nenek Kecamatan Tapung Hulu Kabupaten Kampar. Jom Faperta, 2 (2), 1-10.

Hasibuan, M. S. (2011). Manajemen: Dasar, Pengertian, Dan Masalah. Jakarta: Bumi Aksara

Hariyanto, K., \& Satoto, E. B. (2016). Kriteria Yang Berpengaruh Dalam Penilaian Kinerja Karyawan Menggunakan Anaytical Hierarchy Process. JITI , 15 (1), 1926. 
Purnomo, A. E., \& Suprapto, W. (2015). Analisis Motivasi Kerja Dan Pelatihan Sumber Daya Manusia Untuk Peningkatan Kinerja Karyawan Pada Pt. Musayu Primatama Raya. Agora, 3 (2), 1-8.

Samuel Brindianes., N. K. (2017). Produktivitas Tenaga Kerja Panen Kelapa Sawit Dan Faktor-Faktor Yang Mempengaruhinya Pada Unit Usaha Batang Hari Di Ptpn Iv Jambi. Agrica, 10 (1), 74-85.

Simanjuntak, R. B., Uker, D., \& Zuki, M. (2019). Penilaian Kinerja Operator Pabrik Cpo Di Pt. Daria Dharma Pratama (Ddp) Lubuk Bento Dengan Metode Ahp Dan Rating Scale . Agroindustri, 8 (2), 1-8.

Sofyandi, H., \& Garniwa, I. (2007). Perilaku Organisasional. Yogyakarta: Graha Ilmu.

Sutrisno. (2012). Manajemen Sumber Daya Manusia. Jakarta: Prenada Media Group.

Yulihartika, R. D. (2018). Analisis Permintaan Tenaga Kerja Buruh Harian Lepas Pada Perkebunan Pt. Sandabi Indah Lestari (Sil) Bengkulu Utara. Agroqua, 16 (1), 1-11.

Yuningsih, I., \& Pasaribu, E. (2014). Pengaruh Upah, Pengalaman Kerja Dan Semangat Kerja Terhadap Produktivitas Karyawan Pada Pt. Lingga Tiga Sawit Sigambal. Ecobisma , 1 (1), 90-97.

Yusuf, N. (2018). Pengaruh Kepemimpinan, Tanggung Jawab, Kedisiplinan Dan Kerja Sama Terhadap Kinerja Pegawai Di Universitas Gorontalo. Gorontalo Development, 1 (1), 1-14.

Zein, D. R., Setyaningrum, R., \& Marlinae, L. (2016). Pengaruh Usia, Pendidikan Dan Jaminan Sosial Terhadap Kepuasan Kerja Karyawan Bagian Operator Di Pt. Cakrawala Putra Bersama. Publikasi Kesehatan Masyarakat Indonesia , 3 (2), 38-44. 